\title{
COMPATIBILITY OF UNILATERAL OPTION CLAUSES WITH THE EUROPEAN CONVENTION ON HUMAN RIGHTS
}

\author{
Pavlo Malyuta*
}

\begin{abstract}
This article assesses the compatibility of unilateral option clauses with the ECHR. It distinguishes between the two types of such agreements: unilateral arbitration and unilateral litigation clauses. Unilateral arbitration agreements establish litigation as a default rule with an arbitration exception exercisable exclusively by a designated party (the beneficiary). Unilateral litigation clauses provide for arbitration as the default dispute resolution mechanism, but one party (the beneficiary) can choose litigation. The article argues that these clauses affect the safeguards of Article 6 ECHR differently. More specifically, I submit that unilateral litigation clauses entail a waiver of both the right of access to a court and the right of equal access to a court by the nonbeneficiary, whereas unilateral arbitration agreements result in a waiver by the nonbeneficiary only of the right of equal access to a court. The article further analyses unilateral option clauses in light of the requirements for a valid waiver of a right developed by the ECtHR. The paper concludes that these clauses are compatible with the ECHR because they constitute a valid waiver of the right of equal access to a court.
\end{abstract}

\section{A. INTRODUCTION}

While an arbitration agreement obliges both parties to refer any future disputes between them to arbitration, unilateral option clauses adopt a different approach. These types of arbitration agreements provide one party (the beneficiary) with the advantage of choosing either litigation or arbitration, whereas the other party (the non-beneficiary) is confined to only one type of dispute resolution. More specifically, a unilateral litigation clause provides for the resolution of disputes in arbitration and grants a litigation option to one of the parties, whereas a unilateral arbitration agreement binds the parties to refer their disputes to the courts of a particular jurisdiction but also gives one party an additional power to submit the claim to arbitration.

This article examines unilateral option clauses from the perspective of the European Convention on Human Rights (hereafter, 'ECHR'). The European Court of Human Rights (hereafter, 'ECtHR') has consistently held that the concept of an arbitration agreement is compliant with the ECHR since it constitutes a valid waiver of a right to a court protected under Article 6 ECHR. However, this does not automatically entail that unilateral option clauses are also compatible with the ECHR. This article argues that unilateral option agreements affect the rights guaranteed by Article 6 ECHR differently from an arbitration clause. It analyses the decisions of Russian and English

\footnotetext{
${ }^{*}$ LLM (Stockholm University, Sweden), Bachelor of Law (Kyiv-Mohyla Academy, Ukraine). I am grateful to Professor Andreas von Goldbeck for supervising an earlier version of this paper. I am also grateful to Josephine Dooley for her helpful comments. All errors and omissions are entirely my own.
} 
courts with the aim of determining what rights in Article 6 ECHR are triggered by unilateral option agreements. The article submits that a unilateral litigation clause entails a waiver by the non-beneficiary of both the right of access to a court and the right of equal access to a court. In contrast, a unilateral arbitration agreement results only in a waiver of the right of equal access to a court by the non-beneficiary. The article then applies the requirements for a valid waiver of a right developed by the ECtHR to conclude that unilateral option clauses are a valid waiver of the right of equal access to a court and are therefore compatible with the ECHR.

The article explains the key features of unilateral option clauses in section B and scrutinises the relationship between arbitration and the ECHR in section C. Building upon this background, section D identifies the principles of Article 6 ECHR affected by unilateral option agreements. Section E demonstrates the different effects of unilateral arbitration and litigation clauses on the safeguards of Article 6 ECHR. Section F assesses whether unilateral option clauses constitute a valid waiver of the right of equal access to a court.

\section{B. BACKGROUND}

A unilateral dispute resolution agreement provides one party with the power to choose the forum in which to bring a dispute but deprives the other party of the same opportunity. ${ }^{1}$ These clauses are frequently used in loan agreements between banks or financial institutions, on the one hand, and commercial enterprises or consumers, on the other. $^{2}$ Unilateral dispute resolution agreements appear in different shapes. For example, these clauses often empower a borrower to institute the proceedings only in the courts of a particular jurisdiction (or only in arbitration), whereas a lender can bring its claim before the competent courts of any state (or may choose either arbitration or litigation). ${ }^{3}$ Similar clauses are also encountered in charter parties, tenancy, and employment contracts. ${ }^{4}$ They are usually included in a contract in consideration for the higher risk assumed by the beneficiary of the option, although this is not always the

\footnotetext{
${ }^{1}$ Maxi Scherer, 'Chapter 1: A Cross-Channel Divide Over Unilateral Dispute Resolution Clauses' in Bachir Georges Affaki and Horacio A Grigera Naón (eds), Jurisdictional Choices in Times of Trouble (International Chamber of Commerce 2015) 10.

${ }^{2}$ Philip Clifford and Oliver Browne, 'Finance Agreements: A Practical Approach to Options to Arbitrate' (2009) 1 GAR 39, 39.

3 ibid.

4 Deyan Draguiev, 'Unilateral Jurisdiction Clauses: The Case for Invalidity, Severability or Enforceability' (2014) 31 JIA 19, 21.
} 

Rights

case. ${ }^{5}$ The significant feature of unilateral dispute resolution clauses is that they are tailored for the benefit of an economically stronger party and are primarily aimed at ensuring that a creditor has a number of ways to enforce its rights against the debtor's assets. $^{6}$

Unilateral dispute resolution agreements may be either pure choice of court clauses - known as unilateral or asymmetrical jurisdiction agreements ${ }^{7}$ — or they may include an arbitration option. This article deals with the latter type of clauses and refers to them as 'unilateral option clauses' or 'unilateral option agreements'. Such clauses constitute a special type of an arbitration agreement. ${ }^{8}$ Both an arbitration agreement and a unilateral option clause imply the exclusion of courts' jurisdiction. However, in the case of a unilateral option clause the exclusion takes place when the beneficiary commences arbitration proceedings, whereas for an arbitration agreement this occurs when the parties sign the agreement.

There are two forms of unilateral option agreements: unilateral arbitration clauses and unilateral litigation clauses. ${ }^{9}$ Unilateral arbitration clauses bind the parties to refer their disputes to the courts of a particular jurisdiction, but also give one party an additional power to submit a claim to arbitration. ${ }^{10}$ In other words, unilateral arbitration agreements establish litigation as a default rule with an arbitration exception exercisable exclusively by a designated party. ${ }^{11}$ By contrast, unilateral litigation clauses, which are less common, provide for the resolution of disputes in arbitration and grant a litigation option to one of the parties. ${ }^{12}$ Here, the default dispute resolution mechanism is arbitration, but one party can choose litigation. ${ }^{13}$ A party with the power

\footnotetext{
${ }^{5}$ Lauren D Miller, 'Is the Unilateral Jurisdiction Clause No Longer an Option? Examining Courts' Justifications for Upholding or Invalidating Asymmetrical or Unilateral Jurisdiction Clauses' (2016) 51 TILJ 321, 324

${ }^{6}$ Draguiev (n 4) 21.

${ }^{7}$ Richard Fentiman, 'Unilateral Jurisdiction Agreements in Europe' (2013) 72 C.L.J. 24, 24; Tolek Petch, 'The Treatment of Asymmetric Jurisdiction Clauses in Financial Contracts in France and England' (2016) 5 UCL JL and J 313, 314.

${ }^{8}$ Duarte Gorjão Henriques, 'Asymmetrical Arbitration Clauses under the Portuguese Law' (2011) 11 YAR 44, 45.

${ }^{9}$ Simon Nesbitt and Henry Quinlan, 'The Status and Operation of Unilateral or Optional Arbitration Clauses' (2006) 22 AI 133, 134.

${ }^{10}$ Jane Willems, 'Chapter 38: The Arbitrator's Jurisdiction at Risk: The Case of Hybrid and Asymmetrical Arbitration Agreements' in Patricia Shaughnessy and Sherlin Tung (eds), The Powers and Duties of an Arbitrator: Liber Amicorum Pierre A Karrer (Kluwer Law International 2017) 413.

${ }^{11}$ Nesbitt and Quinlan (n 9) 134.

12 Willems (n 10) 413.

${ }^{13}$ Nesbitt and Quinlan (n 9) 134.
} 
of choice under a unilateral option clause is commonly referred to as the 'beneficiary', whereas a party confined to either litigation or arbitration is the 'non-beneficiary'. 14

An important feature of both the unilateral arbitration clause and the unilateral litigation clause is that the beneficiary can exercise its option at the time of initiation of proceedings as a claimant, as well as after the other party has commenced proceedings as the defendant. For example, when the non-beneficiary of a unilateral arbitration agreement commences proceedings before a court, the beneficiary may rely on an arbitration option and request the court to refer the dispute to arbitration. ${ }^{15}$ Similarly, if the non-beneficiary of a unilateral litigation clause institutes arbitration, the beneficiary can exercise its litigation option and request the arbitral tribunal to refer the dispute to litigation. ${ }^{16}$

The attitude of European jurisdictions towards unilateral dispute resolution agreements varies significantly. ${ }^{17}$ Although courts in most states, including the United Kingdom, Switzerland, Sweden, Spain, Greece and Belgium, ${ }^{18}$ uphold such clauses, they have been treated with greater hostility in recent years. Courts have employed different methods to invalidate unilateral dispute resolution agreements. In particular, French and Bulgarian courts have relied on mandatory provisions of their national contract law. ${ }^{19}$ The French Cour de Cassation invalidated a unilateral dispute resolution agreement because of its 'potestative character', ${ }^{20}$ while the Bulgarian Supreme Court of Cassation held that a similar clause was against 'good morals' ${ }^{21}$

\footnotetext{
${ }^{14}$ Bas van Zelst, 'Unilateral Option Arbitration Clauses in the EU: A Comparative Assessment of the Operation of Unilateral Option Arbitration Clauses in the European Context' (2016) 33 JIA 365, 367.

${ }^{15}$ See NB Three Shipping Ltd v Harebell Shipping Ltd [2004] APP LR 10/13 [11].

${ }^{16}$ See Debenture Trust Corp plc v Elektrim Finance BV and others [2005] 1 All ER (Comm) 476 [493].

${ }^{17}$ Clifford Chance, 'Unilateral Option Clauses - 2017 Survey' (Clifford Chance, 25 January 2017) <https://www.cliffordchance.com/briefings/2017/01/unilateral_optionclauses-2017survey.html> accessed 15 May 2018, 3.

18 ibid.

${ }^{19}$ French Civil Code (before 2016 reform), Article 1170; Bulgarian Contracts and Obligations Act, Article 26(1).

${ }^{20}$ Judgment of 26 September 2012, X v Banque Privée Edmond de Rothschild Europe, Cass. Civ. (1ère) (French Cour de Cassation). For comment see Maxi Scherer, 'The French Rothschild Case: A Threat for Unilateral Dispute Resolution Clauses?' (Kluwer Arbitration Blog, 18 July 2013) $<$ http://arbitrationblog.kluwerarbitration.com/2013/07/18/the-french-rothschild-case-a-threat-forunilateral-dispute-resolution-clauses/> accessed 15 May 2018.

${ }^{21}$ Judgment no 71 in commercial case no 1193/2010 (2 September 2011, Bulgarian Supreme Court of Cassation). For comment see Gilles Cuniberti, 'Bulgarian Court Strikes Down One Way Jurisdiction Clause' (Conflict of Laws net, 13 November 2012) <http://conflictoflaws.net/2012/bulgarian-courtstrikes-down-one-way-jurisdiction-clause/> accessed 15 May 2018.
} 
Further, the Supreme Arbitrazh Court of the Russian Federation invalidated a unilateral litigation agreement for 'violating the balance of the parties' rights'. ${ }^{22}$ In support of its position, the Russian court referred to Article 6 ECHR and the corresponding jurisprudence of the ECtHR. Although the way the Russian court applied the ECHR has been subject to criticism, ${ }^{23}$ neither case law nor commentary contains a detailed inquiry into its overall conclusion on the compatibility of unilateral option clauses with the ECHR.

The ECtHR has also not yet dealt with the issue; the only scholarship to date which examines unilateral option agreements in light of the ECHR is Van Zelst's February 2018 article. ${ }^{24}$ Zelst's analysis focuses on the validity of unilateral arbitration agreements under the ECHR. This paper takes a step further by analysing both unilateral arbitration and unilateral litigation clauses and by adopting a different approach to assessing their compatibility with the ECHR. Before articulating the approach, this article adopts, it is necessary to set out the principles on which it will be based.

\section{RELATIONSHIP BETWEEN UNILATERAL OPTION CLAUSES AND THE ECHR}

An answer to the question whether unilateral option clauses are compatible with the ECHR is premised on the general principles of the interrelation between arbitration and the ECHR. This section aims to provide the background to these principles insofar as it is relevant to the assessment of unilateral option clauses. It firstly analyses how the court seised may characterise the question of unilateral option clauses' compatibility with the ECHR. The section then determines the place of arbitration in the ECHR system and distinguishes two types of safeguards contained in Article 6 ECHR: those applicable before and after the initiation of the proceedings. It further explores how the

\footnotetext{
${ }^{22}$ Russian Telephone Company CJSC v Sony-Ericsson Mobile Communications Rus LLC Case no BAC1831/12 (19 June 2012, Supreme Arbitrazh Court of the Russian Federation) (in Russian, translation by the author) <http://cisarbitration.com/wp-content/uploads/2012/09/Sony-Ericsson-Resolution.pdf> accessed 15 May 2018, 7. For comment see Yelena E Archiyan, 'Fate of the Unilateral Option Clause Finally Decided in Russia' (NYU Journal of International Law and Politics, 10 April 2013) <http://nyujilp.org/fate-of-the-unilateral-option-clause-finally-decided-in-russia/\#FN0> accessed 15 May 2018.

${ }^{23}$ See Anton Asoskov, 'Chapter 3: Unilateral Optional Dispute Resolution Clauses - From Russia with Prejudice' in Bachir Georges Affaki and Horacio A Grigera Naón (eds), Jurisdictional Choices in Times of Trouble (International Chamber of Commerce 2015) 58; Draguiev (n 4) 35.

${ }^{24}$ Bas van Zelst, 'Unilateral Option Arbitration Clauses: An Unequivocal Choice for Arbitration under the ECHR?’ (2018) 25 MJECL 77.
} 
ECtHR treats traditional arbitration agreements and the extent that an arbitration agreement excludes the application of the ECHR's guarantees.

\section{Characterisation of Unilateral Option Clauses' Compatibility with the ECHR}

The characterisation of unilateral option clauses' compatibility with the ECHR by a court is dependent on the circumstances in which it is raised. This issue can be invoked at the beginning of the proceedings, during a set-aside action, or at the awardenforcement stage.

At the outset of a dispute, some of the common situations where a national court may be required to assess the compatibility of a unilateral option clause with the ECHR include the following:

- the non-beneficiary of a unilateral litigation clause initiates litigation in breach of a clause, and the beneficiary requests under Article II(3) of the New York Convention on the Recognition and Enforcement of Foreign Arbitral Awards (hereafter, 'NYC') that the court refer the dispute to arbitration. At this point, Article II(3) NYC requires a national court to assess whether an arbitration agreement 'is null and void, inoperative or incapable of being performed' ${ }^{25}$ Although Article II(3) NYC is silent on the issue of applicable law, most authorities employ the rule enshrined in Article V(1)(a) NYC, which also applies to the recognition of arbitration agreements. ${ }^{26}$ Consequently, the arbitration clause is analysed 'under the law to which the parties have subjected it' or, if they failed to choose the law governing arbitration agreement, under the law of the seat. ${ }^{27}$ Hence, if the applicable law is that of an ECHR Contracting State, the court will examine whether a unilateral litigation clause is valid under the ECHR;

- even if the law applicable to a unilateral litigation clause is a jurisdiction which is not an ECHR Contracting State, if the court seised is situated in a Contracting State, the agreement's compatibility with the ECHR can be still relevant. A court might need to consider whether to decline jurisdiction on the basis of a unilateral litigation clause would amount to a violation of Article 6 ECHR and therefore its public policy.

\footnotetext{
${ }^{25} \mathrm{NYC}$, Article II(3).

${ }^{26}$ For an overview of authorities and case law, see Gary B Born, International Commercial Arbitration (2nd ed, Kluwer Law International 2014) 496-99.

${ }^{27}$ NYC, Article V(1)(a).
} 
Although Article II(3) NYC does not specify public policy as a ground for refusing a request for referral to arbitration, some authors maintain that Article $\mathrm{V}(2)(\mathrm{b}) \mathrm{NYC}$, which allows non-enforcement of an award on the basis of public policy, can be applied by analogy to the enforcement of arbitration agreements under Article II(3) NYC. ${ }^{28}$ The rationale of the public policy consideration in relation to unilateral option clauses is that a national court, being an integral part of the state, is under an obligation to act in accordance with the ECHR. ${ }^{29}$ If it fails to do so, an individual can claim a violation of his rights before the ECtHR. ${ }^{30}$ Thus, a national court might need to determine whether to enforce a unilateral litigation clause would unjustifiably deprive an individual of a right to a court protected by the ECHR. To answer this question, a court will have to assess whether a unilateral litigation clause is valid under its national law, including the ECHR, irrespective of the law applicable to a unilateral litigation agreement. If a court concludes that the clause is invalid under the ECHR, the act of enforcing it by declining jurisdiction over the dispute will constitute a breach of the state's obligation under the ECHR to guarantee each individual access to a court and will, therefore, contradict the state's public policy; or

- where the non-beneficiary of a unilateral arbitration clause initiates litigation, a beneficiary may rely on its arbitration option and ask the court to refer the dispute to arbitration. In this situation, the same considerations relating to the validity of a unilateral arbitration clause and public policy apply as in the fact patterns described above.

In the course of a set-aside action, a unilateral option clause's compatibility with the ECHR might be raised:

- under Article 34(2)(a) of the United Nations Commission on International Trade Law's Model Law on International Commercial Arbitration ${ }^{31}$ (hereafter, 'MAL') as a matter of the arbitration agreement's validity, in case the parties

\footnotetext{
${ }^{28}$ Dorothee Schramm and Elliott Geisinger, 'Article II' in Herbert Kronke, Patricia Nacimiento, Dirk Otto and Nicola Christine Port (eds), Recognition and Enforcement of Foreign Arbitral Awards: A Global Commentary on the New York Convention (Kluwer Law International 2010) 105.

${ }^{29}$ Aleksandar Jaksic, 'Procedural Guarantees of Human Rights in Arbitration Proceedings' (2007) 24 JIA $159,162$.

${ }^{30}$ James J Fawcett, 'The Impact of Article 6(1) of the ECHR on Private International Law' (2007) 56 ICLQ 1, 2.

${ }^{31}$ If a court deciding the case is in a MAL jurisdiction.
} 
have subjected their unilateral option clause to the law of an ECHR Contracting State or if the seat of arbitration is in an ECHR Contracting State; or

- under Article 34(2)(b)(ii) as a question of whether an award rendered on the basis of a unilateral option clause is in conflict with the public policy of the seat of arbitration.

At the stage of recognition and enforcement of an award issued under a unilateral option clause, an enforcing court might have to assess whether the agreement is compatible with the ECHR:

- under Article V(1)(a) NYC when analysing the validity of an arbitration agreement, in case the parties have subjected their unilateral option clause to the law of an ECHR Contracting State or if the seat of arbitration was in an ECHR Contracting State; or

- under Article V(2)(b) NYC when determining whether to enforce an award rendered on the basis of a unilateral option clause would amount to the violation of the public policy of a state.

Therefore, the question whether the ECHR precludes unilateral option clauses can be characterised by the court seised either as a matter of public policy or of the arbitration agreement's validity. These notions can be invoked at the outset of arbitral proceedings, during a set-aside action or at the enforcement stage. Which of the two concepts will be employed is determined by the circumstances of the case - in particular, the law applicable to a unilateral option clause and the state in which the court seised is situated. Having established the situations where the parties might be able to question the validity of a unilateral option clause, the subsequent sections will explore the premises which can underpin their arguments.

\section{Relationship between Arbitration and the ECHR}

The discussion on the relationship between the ECHR and arbitration normally focuses on contrasting the two. The reason for this is that the main purpose of an arbitration agreement is to exclude the jurisdiction of national courts over any potential dispute between the parties. ${ }^{32}$ In contrast, the ECHR's purpose is to establish the obligations of state organs, including courts, in the area of human rights protection. ${ }^{33}$ Hence, arbitration is viewed as an instrument for the partial exclusion of human rights

\footnotetext{
${ }^{32}$ Born (n 26) 1270.

${ }^{33}$ Oliver Dörr, 'European Convention on Human Rights' in Stefanie Schmahl and Marten Breuer (eds), The Council of Europe: Its Law and Policies (Oxford University Press 2017) para 22(16).
} 

Rights

guarantees relating to a fair trial contained in Article 6 ECHR. Although the ECHR's case law suggests that the above view is largely true, ${ }^{34}$ arbitration can also be viewed as a way of achieving some of the ECHR's objectives.

There are two principles in the ECHR's system relevant to determine the interrelation between the ECHR and arbitration: access to justice and access to a court.

Access to justice is not explicitly mentioned in the ECHR, ${ }^{35}$ or in any other international human rights instrument. ${ }^{36}$ It is therefore a descriptive rather than a legal notion. ${ }^{37}$ Access to justice is normally interpreted to encompass Article 6 ECHR (a right to a fair trial) and Article 13 ECHR (a right to an effective remedy). ${ }^{38}$ Hence, access to justice is a broader concept than access to a court. ${ }^{39}$ Access to justice denotes the ability of a party to seek and obtain a remedy for a violation of his rights through either formal or informal institutions. ${ }^{40}$ Arbitration constitutes one of the means to access justice. ${ }^{41}$ Thus, even though by entering into an arbitration agreement the parties waive certain rights guaranteed by the ECHR, arbitration should not be perceived as being detached from the ECHR's system. It plays a role in furthering the ECHR's objectives by providing individuals with a special mechanism to obtain a remedy for the violation of their rights.

Arbitration is more commonly discussed in the context of Article 6 ECHR, and whether and to what extent the guarantees established under the provision apply to arbitral proceedings. Article 6 ECHR protects the right to a fair trial, which contains

\footnotetext{
${ }^{34}$ See the detailed discussion in the subsequent section $\mathrm{C}(3)$.

${ }^{35}$ Janneke H Gerards and Lize R Glas, 'Access to Justice in the European Convention on Human Rights System' (2017) 25 Netherlands Quarterly of Human Rights 11, 13; European Union Agency for Fundamental Rights, Access to Justice in Europe: an Overview of Challenges and Opportunities (Publications Office of the EU 2011) 14.

${ }^{36}$ Council of Europe Committee on Equality and Non-Discrimination, Equality and Non-Discrimination in the Access to Justice Report (31 March 2015) <http://assembly.coe.int/nw/xml/XRef/XrefXML2HTML-en.asp?fileid=21619\&lang=en> accessed 17 March 2019 para 6.

37 ibid.

${ }^{38}$ Gerards and Glas (n 35) 15; European Union Agency for Fundamental Rights, Handbook on European Law Relating to Access to Justice (Publications Office of the EU 2016) 16; European Union Agency for Fundamental Rights, Access to Justice in Europe: an Overview of Challenges and Opportunities ( $\mathrm{n}$ 35) 14; Council of Europe Committee on Equality and Non-Discrimination (n 36) para 1.

${ }^{39}$ Gerards and Glas (n 35) 15.

${ }^{40}$ United Nations Development Programme, 'Programming for Justice: Access for All: A Practitioner's Guide to Human Rights-Based Approach to Access to Justice' (United Nations Development Programme 2005) <https://www.un.org/ruleoflaw/files/Justice_Guides_ProgrammingForJustice-AccessForAll.pdf> accessed 17 March 20195.

${ }^{41}$ Lithgow and others $v$ United Kingdom App no 9006/80 (ECtHR, 8 July 1986) [201] cited in Stephan W Schill, 'Developing a Framework for the Legitimacy of International Arbitration' in Albert Jan van den Berg (ed), Legitimacy: Myths, Realities, Challenges (Kluwer Law International 2015) 825; European Union Agency for Fundamental Rights, Handbook on European Law Relating to Access to Justice (n 38) 48.
} 
several guarantees, either expressly articulated in the ECHR or developed by the ECtHR's jurisprudence. ${ }^{42}$ The most relevant part of Article 6 ECHR reads as follows:

In the determination of his civil rights and obligations (...) everyone is entitled to a fair and public hearing within a reasonable time by an independent and impartial tribunal established by law. Judgment shall be pronounced publicly $(\ldots) .^{43}$

For the purposes of this article, the safeguards of Article 6 ECHR can be divided into two groups; those applicable before and after the initiation of the proceedings. The former safeguards are relevant to determining the validity of an arbitration agreement or a unilateral option clause, whereas the latter are material for assessing the legality of an arbitral procedure.

Before an action is brought, Article 6 ECHR protects the right of access to a court, which the ECtHR defines as the right to initiate proceedings before a state court. ${ }^{4}$ Although it does not contain express language to that effect, the ECtHR held in Golder $v$ United Kingdom that the right of access is inherent in Article 6 and rejected the argument that Article 6 is only applicable to an action that has already been initiated. ${ }^{45}$ The ECtHR reasoned that it would be irrational to establish extensive procedural guarantees for pending litigation, without first securing an ability to initiate the proceedings. ${ }^{46}$

With respect to an instituted action, Article 6 ECHR contains requirements applicable to the conduct of the proceedings and the composition of a court. The range of guarantees available in this category are considerably wider than those before the initiation of proceedings. The safeguards of this group include the principles of equality of arms, adversarial proceedings, and public hearing; the rights to be present at the hearing and to a trial within reasonable time; and the independence and impartiality of a judge. $^{47}$

To sum up, arbitration can be seen both as a way to partially exclude the application of guarantees contained in Article 6 ECHR and a means to ensure access to justice for an individual as required by Articles 6 and 13 ECHR. Article 6 ECHR

\footnotetext{
${ }^{42}$ See Golder $v$ the United Kingdom App no 4451/70 (ECtHR, 21 February 1975) [36].

${ }^{43}$ ECHR Article 6(1).

${ }^{44}$ Golder (n 42) [36].

45 ibid [35].

46 ibid [35].

${ }^{47}$ See William Schabas, The European Convention on Human Rights: A Commentary (OUP 2015) 288.
} 
provides the parties to a dispute with rights applicable not only after the institution of the proceedings but also before a claim is brought. Only the latter category of safeguards is relevant for assessing the compatibility of unilateral option clauses with the ECHR because such agreements affect the position of the parties before an action is instituted, rather than within an already initiated procedure. Before moving on to determine the guarantees of Article 6 ECHR affected by unilateral option clauses, it is instructive to first explore the impact of a traditional arbitration agreement on the same provision.

\section{Waiver of Guarantees Contained in Article 6 ECHR}

By entering into an arbitration agreement, the parties undertake an obligation not to bring their claims before a national court. ${ }^{48}$ It follows that this arrangement runs contrary to a right of access to a court protected under Article 6 ECHR. However, the ECtHR considers an arbitration agreement to be a valid waiver of this right, ${ }^{49}$ provided that it satisfies certain requirements. ${ }^{50}$ At the same time, arbitration cannot entail a complete renunciation of all safeguards contained in Article 6 ECHR. This has been consistently confirmed by the European Commission and the ECtHR in their jurisprudence.

The European Commission in $X v$ Federal Republic of Germany held that the ECHR does not prohibit 'partial renunciation' of rights contained in Article 6 ECHR. ${ }^{51}$ It found that an arbitration agreement constitutes a partial renunciation of Article 6 ECHR. ${ }^{52}$ The European Commission focused on rights of Article 6 ECHR applicable after a procedure is initiated and failed to mention the right of access to a court. This is unsurprising since the judgment in Xv Federal Republic of Germany was rendered in 1962, whereas the right of access to a court was recognised by the ECtHR for the first time only in Golder, in $1975 .{ }^{53}$ Nevertheless, these decisions read together necessarily imply that traditional arbitration clauses constitute a valid waiver of the right of access to a court protected under Article 6 ECHR.

\footnotetext{
${ }^{48}$ Born (n 26) 1270.

${ }^{49}$ Nigel Blackaby, Constantine Partasides, Alan Redfern and Martin Hunter, Redfern and Hunter on International Arbitration (6th edn, OUP 2015) 589.

${ }^{50}$ See section $\mathrm{F}$ below for the detailed discussion of the requirements.

${ }^{51}$ X v Federal Republic of Germany App no 1197/61 (Commission Decision, 5 March 1962).

52 ibid.

${ }^{53}$ Golder (n 42).
} 
Another judgment which illustrates a positive attitude of the ECtHR towards arbitration agreements is Deweer $v$ Belgium. ${ }^{54}$ Although the case concerned issues of criminal law, the judgment contains important insight into the ECtHR's view on arbitration. The ECtHR noted that a waiver of rights contained in Article 6 ECHR is often encountered 'in the shape of arbitration clauses in contracts'. ${ }^{55}$ The ECtHR outlined two characteristics of such a waiver. First, it does not violate the ECHR 'in principle'. ${ }^{56}$ By employing this wording, the ECtHR made clear that not every arbitration agreement can be considered a valid waiver of Article 6 ECHR. Second, the ECtHR assumed that a waiver in the form of an arbitration clause has 'undeniable advantages for the individual'. ${ }^{57}$ When taking this position, the ECtHR most probably had in mind traditional arbitration agreements where both parties are obliged to refer potential disputes to arbitration. It is questionable whether the ECtHR would express the same attitude towards unilateral option clauses. In light of court decisions in various jurisdictions invalidating unilateral option clauses on the grounds of their prejudice towards one of the parties, ${ }^{58}$ describing these agreements as undeniably advantageous for both parties appears to be unconvincing.

In Suovaniemi and others $v$ Finland, the ECtHR reiterated that an arbitration agreement does not per se contradict Article 6 ECHR and is 'in principle acceptable'. ${ }^{59}$ At the same time, this does not mean that an arbitration clause waives all of rights contained in Article 6. ${ }^{60}$ The ECtHR further reasoned that since Article 6 ECHR guarantees a wide range of rights, the permissibility of a waiver in respect of each one of them may have to be assessed independently:

Waiver may be permissible with regard to certain rights but not with regard to certain others. A distinction may have to be made even between different rights guaranteed by Article $6 .^{61}$

In other words, the ECtHR implies that an arbitration agreement, apart from being a renunciation of the right of access to a court, can be considered an automatic, valid waiver of certain procedural safeguards contained in Article 6 ECHR. At the same

\footnotetext{
${ }^{54}$ Deweer v Belgium App no 6903/75 (ECtHR, 27 February 1980).

55 ibid [49].

56 ibid.

${ }^{57}$ ibid.

${ }^{58}$ See Clifford Chance Survey (n 17).

${ }^{59}$ Suovaniemi and others v Finland App no $31737 / 96$ (ECtHR, 23 February 1999).

${ }^{60} \mathrm{ibid}$.

${ }^{61}$ ibid.
} 
time, other guarantees under Article 6 merit separate assessment of the permissibility of waiving them.

The most obvious example of a safeguard that an arbitration agreement waives together with the right of access to a court is an entitlement to a public hearing, ${ }^{62}$ which the ECtHR has expressly recognised. ${ }^{63}$ This is implicated in the very nature of arbitration, where confidentiality of proceedings is one of its primary features. ${ }^{64}$ Arguably, another automatically waivable guarantee is the right to a decision 'within a reasonable time', since neither a national court nor the ECtHR is legally or practically capable of controlling the duration of arbitral proceedings. ${ }^{65}$ On the other hand, authorities generally agree that the right to a fair and equal treatment and the right to an independent and impartial tribunal cannot be waived by the mere signing of an arbitration clause. ${ }^{66}$ However, in light of scarce guidance from the ECtHR, the situation becomes ambiguous with respect to specific arbitral practices which are potentially at odds with Article 6 ECHR. Benedettelli points to a number of features of arbitration which may be incompatible with Article 6 ECHR including, inter alia, the exclusion of a party representative appointed after the constitution of the arbitral tribunal if the appointment may jeopardise the independence and impartiality of arbitrators, ${ }^{67}$ the procedure for the appointment of an arbitrator in multi-party proceedings which does not ensure equality between parties; the lack of remedies against decisions of arbitral institutions on arbitrator challenges; and the limited requirements for a reasoned decision in an arbitral award. ${ }^{68}$ The issue is then whether and to what extent Article 6 ECHR precludes similar practices and whether a party to an arbitration agreement can resist them by invoking the ECHR.

A detailed inquiry into the compatibility of certain arbitral practices with Article 6 ECHR is outside the scope of the present article. What is important for the purposes

\footnotetext{
${ }^{62}$ Blackaby (n 49) 589.

${ }^{63}$ Nordström $v$ the Netherlands App no 28101/95 (ECtHR, 27 November 1996).

${ }^{64}$ Julian Lew, Loukas Mistelis and Stefan Kroll, Comparative International Commercial Arbitration (Kluwer Law International 2003) 91.

65 Juan Carlos Landrove, 'European Convention on Human Rights' Impact on Consensual Arbitration: An État Des Lieux of Strasbourg Case Law and of a Problematic Swiss Law Feature' in Samantha Besson and Michel Hottelier (eds), Human Rights at the Centre (Schulthess 2006) 86.

${ }^{66}$ See an overview of the literature in Toms Kruminš, 'Arbitration in Latvia: A Cautionary Tale?' (2017) 34 JIA 303, 314; Landrove (n 65) 86.

${ }^{67}$ International Bar Association, IBA Guidelines on Party Representation in International Arbitration (25 May 2013) <https://www.ibanet.org/Document/Default.aspx?DocumentUid=6F0C57D7-E7A043AF-B76E-714D9FE74D7F> accessed 17 March 20196.

${ }^{68}$ Massimo V Benedettelli, 'Human rights as a litigation tool in international arbitration' (2015) 31(4) AI 631, 647-48.
} 
of this research is that by agreeing to an arbitration agreement, parties exclude the applicability of certain safeguards contained in Article 6 ECHR or at least limit the level of protection afforded by them.

\section{Summary}

The purpose of this section was to establish a number of principles which govern the interrelation between the ECHR and arbitration which are relevant to assessing the compatibility of unilateral option clauses with the ECHR. First, an arbitration agreement constitutes a valid waiver of the right of access to a court under Article 6 ECHR. Second, the fact that an arbitration agreement waives the right of access to a court does not entail that other guarantees under Article 6 ECHR are also waived. Third, an arbitration agreement limits the level of protection under Article 6 ECHR. Some features of arbitration entail an automatic waiver of certain rights under Article 6 ECHR. For example, the ECtHR has decided that the confidentiality of arbitration implies the waiver of the right to a public hearing. Since the ECtHR has not provided guidance on how to distinguish waivable and non-waivable guarantees, the compatibility of other arbitral practices with the ECHR is unclear.

The ECtHR has not had an opportunity to render a judgment in respect of unilateral option clauses. Since they are special types of arbitration agreements, their effect on Article 6 ECHR guarantees is not identical to traditional arbitration clauses. Hence, before assessing the compatibility of unilateral option clauses with Article 6 ECHR, it is necessary to establish which right, apart from the right of access to a court, is triggered by these agreements. The subsequent section aims to do this by considering the decisions of courts in two jurisdictions with conflicting perspectives on the issue.

\section{PRINCIPLES OF ARTICLE 6 ECHR AFFECTED BY UNILATERAL OPTION CLAUSES}

This section looks at different approaches to the application of Article 6 ECHR to dispute resolution clauses. It first considers the application of Article 6 ECHR to a unilateral litigation clause by the Russian court, which sparked a discussion on the compatibility of unilateral option clauses with the ECHR. The section then analyses a decision rendered by the English High Court on a choice of court agreement. Although the English case did not involve arbitration, the court's reasoning indicates that Article 6 ECHR can be applied to unilateral option clauses in the form of the right of equal access to a court. 


\section{Unilateral Litigation Clause Invalidated by the Russian Court}

In 2012, the Presidium of the Supreme Arbitrazh Court of the Russian Federation applied the principle of equality of arms contained in Article 6 ECHR to a unilateral litigation clause and declared it invalid. ${ }^{69}$ This approach cannot be sustained since, as discussed in section $\mathrm{C}(2)$, the equality of arms is relevant only to the position of the parties within an already initiated procedure.

The dispute before the Russian court arose out of a mobile phone supply agreement between Sony-Ericsson Mobile Communications Rus LLC and Russian Telephone Company CJSC (hereafter, 'Sony Ericsson case'). The contract contained a dispute resolution provision where both parties agreed to arbitrate, but Sony Ericsson retained the right of access to a court:

Any dispute arising out of this Contract which cannot be settled by negotiations will be finally resolved in accordance with the Rules of Conciliation and Arbitration of the International Chamber of Commerce by three (3) arbitrators appointed in accordance with the Rules (...). This arbitration clause shall not restrict Sony Ericsson to seek the collection of debt for the delivered goods through a competent state court. ${ }^{70}$

The Russian court reasoned that this unilateral litigation agreement was contrary to 'the fundamental principles of protection of civil rights' and decided that the clause was void as it 'violates the balance of the parties' rights'. ${ }^{71}$ In support of its conclusion, the Russian court referred to the principle of equality of arms contained in Article 6 ECHR. It stated that according to the ECtHR's jurisprudence the parties must possess equal procedural opportunities, ${ }^{72}$ and emphasised that the ECHR guarantees the right of a party to be in an equal position in relation to its opponent. ${ }^{73}$ On this basis, the Russian court concluded that a dispute resolution clause cannot provide only one party

\footnotetext{
${ }^{69}$ Sony Ericsson (n 21). Although the decision is clear in treating unilateral litigation clause as unacceptable, its language is ambiguous as to its implications (complete or partial invalidation of the agreement, transformation into bilateral clause, etc.). Consideration of this issue is outside the scope of the present study. For discussion see Alyona N Kucher, Alexey I Yadykin and Anton V Asoskov, 'Asymmetric Dispute Resolution Clauses: Validity Under Russian Law After the Sony Ericsson Jurisprudence' (Lexology, $\quad 28 \quad$ November 2012 ) <https://www.lexology.com/library/detail.aspx?g=16de39c8-352b-4a19-bac7-00cfd9fe12eb> accessed 12 May 2018.

${ }^{70}$ Sony Ericsson (n 21) 3.

71 ibid 7.

72 ibid 6.

73 ibid.
} 
with the right of access to a court while depriving the other one of the same opportunity. ${ }^{74}$

Commentators criticise the application of the ECHR by the Russian court in the Sony Ericsson case. ${ }^{75}$ The first ground is that ECtHR cases mentioned in the judgment concern legal issues and factual circumstances completely unconnected with arbitration or contract law. ${ }^{76}$ Another more substantive ground relates to the misinterpretation of the principle of equality of arms guaranteed by Article 6 ECHR. As demonstrated in section $\mathrm{C}(2)$, this concept is only relevant to procedure that has already been initiated. Since an unequal power to choose a forum has no bearing on the position of the parties within proceedings, the principle of equality of arms is not applicable to dispute resolution clauses. ${ }^{77}$

To sum up, the Russian court incorrectly applied Article 6 ECHR to a unilateral arbitration clause in the Sony Ericsson case. Unilateral option clauses determine rights and obligations of the parties before they begin the dispute resolution process. In contrast, the principle of equality of arms under Article 6 ECHR is only applicable to an already initiated procedure.

2. The English Court's Application of Article 6 ECHR to a Choice of Court Agreement

In 2013, the English High Court applied the principle of equal access to justice under Article 6 ECHR to a choice of court agreement but found that the clause at issue did not violate the ECHR. Despite the fact that the case concerned a dispute resolution agreement without an arbitration element, it is still valuable for the present analysis. The decision of the English court demonstrates that Article 6 ECHR does contain safeguards which can be applied to unilateral option clauses. At the same time, the whole analysis and conclusion cannot be easily transferred to unilateral option clauses. Since the English case concerned a choice of court agreement, it did not involve a waiver of the right of access to a court by one of the parties. When viewed through the lenses of the ECHR, this distinction has important implications, to be discussed in detail in section $\mathrm{E}$.

\footnotetext{
74 ibid 7.

${ }^{75}$ See Asoskov (n 23) 58; Draguiev (n 4) 35.

${ }^{76}$ Asoskov (n 23) 58.

${ }^{77}$ Draguiev (n 4) 35.
} 
The dispute before the English court arose out of a facility agreement between Mauritius Commercial Bank Ltd and Hestia Holdings Limited, with Sujana Universal Industries Limited as guarantor of Hestia's obligations (hereafter, 'Mauritius case'). ${ }^{78}$ The contract contained a choice of court agreement pursuant to which Mauritius was allowed to bring claims anywhere in the world, while Hestia could initiate the proceedings only in England:

'Clause 24.1 [Jurisdiction]

(a) The courts of England have exclusive jurisdiction to settle any dispute arising out of or in connection with this Agreement (including a dispute regarding the existence, validity or termination of this Agreement) (a 'Dispute').

(...)

(c) This Clause 24.1 is for the benefit of the Lender only. As a result, the Lender shall not be prevented from taking proceedings related to a Dispute in any other courts in any jurisdiction. To the extent allowed by law the Lender may take concurrent proceedings in any number of jurisdictions. ${ }^{79}$

Hestia argued that this clause was incompatible with the principle of equal access to justice enshrined in Article 6 ECHR. ${ }^{80}$ The English court rejected the contention by stating obiter that '[A]rticle 6 is directed to access to justice within the forum chosen by the parties, not to choice of forum ${ }^{81}$ Draguiev interprets this passage from the Mauritius case as suggesting that the principle of equality is probably not applicable to unilateral option clauses at all, since 'they only influence the designation of jurisdiction and not the development of the proceedings'. ${ }^{82}$ However, the further reasoning of the English court does not support such a proposition. The English court stated that Hestia failed to identify the forum where its access to justice would be unequal as compared to Mauritius's because of the latter's power of choice. ${ }^{83}$ In other words, the English court found that the broader number of jurisdictions available to the beneficiary does not mean that an opposing party has less access to a court compared

\footnotetext{
${ }^{78}$ Mauritius Commercial Bank Limited v Hestia Holdings Limited and Sujana Universal Industries Limited [2013] EWHC 1328 (Comm).

79 ibid [10].

80 ibid [12].

81 ibid [43].

${ }^{82}$ Draguiev (n 4) 35.

${ }^{83}$ Mauritius (n 78) [43].
} 
to the beneficiary ${ }^{84}$ It follows that a dispute resolution agreement is compatible with Article 6 ECHR if the parties are equally placed in relation to the courts of at least one jurisdiction. Hypothetically, there could have been an agreement that would create unequal access to the courts of England for Hestia as compared to Mauritius. Hence, rather than rejecting the application of the principle of equal access, the English court found that Hestia failed to prove that the agreement under consideration affected its right of equal access to a court.

A comparison between the Sony Ericsson case and the Mauritius case highlights the logic of the English court's reasoning. Unlike the Russian court, which mistakenly based its decision on the equality of arms aspect of Article 6 ECHR, the English court analysed the choice of court agreement from the perspective of the article's guarantee of equal access to a court. Hence, the English court did not deal with the equality of the parties in the same way as the Russian court did. In fact, having analysed the dispute resolution clause in light of the equal access to a court, the English court remedied the awkward argumentation of the Russian court by confirming that the principle of equality of the parties does matter before a procedure is initiated.

\section{Summary}

Neither the Sony Ericsson case nor the Mauritius case adequately answers the question whether unilateral option clauses comply with Article 6 ECHR. However, the analysis of these decisions provides guidance which is useful in constructing a framework for finding a solution to the compatibility issue. First, the principle of equality of arms enshrined in Article 6 ECHR cannot be applied to unilateral option clauses. Second, the equality of the parties is still relevant to unilateral option clauses in the form of the right of equal access to a court.

\section{E. UNILATERAL OPTION CLAUSES AS A WAIVER OF THE RIGHT OF EQUAL ACCESS TO A COURT UNDER ARTICLE 6 ECHR}

The next section demonstrates how unilateral option clauses affect guarantees of Article 6 ECHR applicable before the initiation of the proceedings, namely the right to a court and the right of equal access to a court. It first defines the content of the right of equal

\footnotetext{
${ }^{84}$ Although the judgment in the Mauritius case refers to the equal access to justice, it is unlikely that the English court employed this notion in a broad sense. Since the case dealt with a choice of court issue, it is more reasonable to assume that the English court was referring to equal access to a court as guaranteed by Article 6 ECHR.
} 
access to a court and explains why it is relevant to assessing the compatibility of unilateral option agreements with Article 6 ECHR. The section further distinguishes between the effects of unilateral litigation and arbitration clauses on Article 6 ECHR generally and the right of equal access to a court in particular. It argues that a unilateral litigation clause entails a waiver of both the right of access to a court and the right of equal access to a court by the non-beneficiary, whereas a unilateral arbitration agreement results only in a waiver of the right of equal access to a court. However, this does not automatically mean that Article 6 ECHR precludes unilateral option clauses. Whether such agreements can be valid waivers of the right of equal access to a court and thus compatible with Article 6 ECHR is investigated in section F.

\section{Right of Equal Access to a Court and its Bearing Upon Unilateral Option Clauses}

The right of equal access to a court is neither explicitly mentioned in Article 6 ECHR nor yet articulated by the ECtHR. Nevertheless, international human rights law clearly recognises the concept. ${ }^{85}$ As discussed above, the English court in the Mauritius case considered the right of equal access to a court a part of Article 6 ECHR. ${ }^{86}$ Since the ECtHR interprets the ECHR in light of other international instruments and the practice of European states, ${ }^{87}$ it can be reasonably argued that Article 6 ECHR does protect the equality of access to a court. Human rights law traditionally interprets this guarantee as requiring positive actions by states to ensure that there exists, inter alia, a proper judicial system covering the whole territory of a state and a possibility to obtain legal aid. ${ }^{88}$ At the same time, it also makes sure that there is no legal impediment to accessing a court. ${ }^{89}$ The requirement implies the necessity for the absence in national legislation

\footnotetext{
${ }^{85}$ See Angel N Oló Bahamonde v Equatorial Guinea, Human Rights Committee, Communication No. 468/1991, United Nations Doc CCPR/C/49/D/468/1991 [1993], where the Human Rights Committee stated in respect of Article 14(1) of the International Covenant on Civil and Political Rights that 'the notion of equality before the courts and tribunals encompasses the very access to the courts'; Human Rights Committee, General Comment No. 32: Article 14: Right to equality before courts and tribunals and to a fair trial' CCPR/C/GC/32 (2007) [12]; Declaration of the High-level Meeting of the General Assembly on the Rule of Law at the National and International Levels A/RES/67/1 [14]; Pieter Omzigt, 'Human Rights Compatibility of Investor-State Arbitration in International Investment Protection Agreements' (Parliamentary Assembly of the Council of Europe Committee on Legal Affairs and Human Rights 2017) para 1(1); Amnesty International, Fair Trial Manual (Amnesty International Publications 2014) 106.

${ }^{86}$ See section $\mathrm{D}(2)$.

${ }^{87}$ Demir and Baykara v Turkey App no 34503/97 (ECtHR, 12 November 2008) [85]; National Union of Rail Maritime and Transport Workers $v$ the United Kingdom App no 31045/10 (ECtHR, 8 April 2014) [76].

${ }^{88}$ Daniel Moeckli, International Human Rights Law (OUP 2014) 273.

${ }^{89}$ Council of Europe Committee on Equality and Non-Discrimination (n 36) para 21; Agron Bajri, 'Right to a Fair Trial in the Perspective of European Convention on Human Rights' (2014) 27 MJSS 283, 288.
} 
of provisions restricting access to a court for a certain group of individuals. ${ }^{90}$ However, the decision of the English court in the Mauritius case demonstrates that Article 6 ECHR can also be applied to obstacles generated by private law instruments, particularly dispute resolution agreements. Hence, the right of equal access to a court requires that there should be no impediments, including legal ones, which put an individual in a disadvantageous position compared to others with respect to their right of access to a court.

In the only piece of available scholarship inquiring into the compatibility of unilateral option clauses with the ECHR, Zelst analyses unilateral arbitration clauses solely in terms of a waiver of the right of access to a court. ${ }^{91}$ His approach, however, disregards the peculiarities of unilateral option clauses compared to regular arbitration agreements. If viewed merely from the perspective of the right of access to a court, there is no difference between the two. Both traditional arbitration agreements and unilateral option clauses limit the ability of at least one party to access a court, but the problem with the latter is that they affect the equality between the parties in accessing a court. Moreover, it is questionable to what extent a mere signing of a unilateral arbitration clause can be considered a waiver of the right of access to a court, since it allows both parties to initiate litigation. ${ }^{92}$ For these reasons, the present article assesses the compatibility of unilateral option clauses with the ECHR in light of the right of equal access to a court.

From the perspective of the right of equal access to a court, the problem with unilateral option clauses consists not, as it was in the Mauritius case, in a broader range of options available to the beneficiary for bringing its claim before a decision maker. In Golder $v$ the United Kingdom, the ECtHR reasoned that the right of access to a court is a safeguard which makes it possible to benefit from the procedural guarantees of Article 6 ECHR. ${ }^{93}$ Hence, the problem is that a unilateral option clause places the parties in a different position with regards to access to a procedure, namely litigation, which ought to entirely satisfy standards contained in Article 6 ECHR. As demonstrated in section $\mathrm{C}(3)$, arbitral proceedings are not fully compliant with the requirements of Article 6 ECHR. Additionally, some procedural tools, such as pre-trial discovery or joinder, ${ }^{94}$

\footnotetext{
${ }^{90}$ Moeckli (n 88) 273.

${ }^{91}$ See Bas van Zelst (n 24).

${ }^{92}$ See the detailed discussion in section $\mathrm{E}(2)$ below.

${ }^{93}$ Golder (n 42) [35].

${ }^{94}$ Hans Smit, 'The Unilateral Arbitration Clause: a Comparative Analysis' (2009) 20 ARIA 391, 405.
} 
and remedies, such as the contempt power, ${ }^{95}$ are only available in litigation. It is true that arbitration may be praised as a more effective and thus practically a more beneficial dispute resolution method than litigation. Although this argument might be valid for assessing whether unilateral option clauses can be considered a legitimate waiver of the right of equal access to a court (see section F), it is irrelevant to the present stage of analysis. At this point, it is important that under Article 6 ECHR each individual must possess equal access to litigation with corresponding procedural guarantees. Unilateral option clauses run contrary to this requirement.

\section{Unilateral Litigation Clause v Unilateral Arbitration Clause: Effects on} Article 6 ECHR Distinguished

Unilateral arbitration and unilateral litigation agreements are not identical in their effects on the right of access to a court and the right of equal access to a court. The first difference is that a unilateral litigation clause constitutes a waiver of both of these rights by the non-beneficiary, whereas a unilateral arbitration clause waives only the right of equal access to a court. The second distinction lies in the different ways these agreements influence the equality of access to a court.

A unilateral litigation clause entails a waiver by the non-beneficiary of both the right of access to a court and the right of equal access to a court. After the agreement is signed, the non-beneficiary can no longer bring its claim to a court, while the beneficiary retains this option. Thus, the non-beneficiary, in addition to waiving the right of access to a court, also relinquishes its right of equal access to a court vis-à-vis the beneficiary of a unilateral litigation clause. This means that the non-beneficiary will not be able to have its claim determined in litigation under all of the guarantees provided for in Article 6 ECHR. At the same time, the beneficiary, which has the power to choose either arbitration or proceedings before a national court, retains the ability to potentially benefit from the full range of Article 6 ECHR safeguards in the proceedings, where the claim it brings will be decided. The beneficiary also retains an ability to employ procedural tools which are either available exclusively in litigation or are most effective when ordered by a court. For example, where the circumstances of a dispute suggest that a successful claim will require the extensive taking of evidence from third parties, the beneficiary would likely opt for litigation, as in arbitration this tool is either limited or unavailable, depending on the law applicable to arbitration proceedings. In contrast,

95 Gilles Cuniberti, Rethinking International Commercial Arbitration: Towards Default Arbitration (Edward Elgar Publishing 2017) 29. 
the non-beneficiary does not have a similar advantage, which can sometimes mean that the prospects of proving a particular allegation are so minimal that bringing a claim is futile.

The situation is different where a traditional arbitration agreement is engaged. In this case, both parties waive their right to a court by undertaking an obligation not to initiate litigation, which means that their access to a court is equal. On the contrary, a unilateral litigation clause creates a situation where the non-beneficiary is completely precluded from initiating litigation, while the beneficiary is entirely free to do so. Hence, these agreements result in a waiver by the non-beneficiary of the right of access to a court together with the right of equal access to a court.

By entering into a unilateral arbitration clause, the non-beneficiary waives its right of equal access to a court without waiving the right of access to a court. Since both parties can initiate litigation, and the ECtHR defines the right of access to a court as 'the right to institute proceedings', ${ }^{96}$ the non-beneficiary retains the right of access to a court even after a unilateral arbitration clause is signed. However, even though the nonbeneficiary can institute proceedings before a court, this does not guarantee that the dispute will proceed in litigation; the beneficiary can block an action by exercising its arbitration option. It follows that although under a unilateral arbitration agreement both parties retain an ability to initiate litigation, the beneficiary can trump the nonbeneficiary's access to a court. This results in the situation where the non-beneficiary's access to a court is completely dependent on the will of another party. For this reason, a unilateral arbitration clause results in the renunciation of the right of equal access to a court by the non-beneficiary.

Therefore, in practical terms there is no significant difference between a unilateral arbitration and a unilateral litigation clause for the non-beneficiary. Either way the final choice as to the forum rests with the beneficiary. Even though from a legal standpoint a unilateral arbitration clause provides the non-beneficiary a wider scope of rights under the ECHR, there is a little benefit in being able to institute litigation without also having a chance to obtain a judgment from a court.

The counterargument to the proposition that under unilateral option clauses the parties have unequal access to the safeguards contained in Article 6 ECHR might be that this inequality is merely potential and is remedied at the very moment one party

\footnotetext{
${ }^{96}$ Golder (n 42) [36].
} 
initiates proceedings. For example, where the beneficiary of a unilateral litigation clause institutes proceedings in the court of an ECHR Contracting State, the nonbeneficiary will still enjoy the same protection under the ECHR as the beneficiary. When the beneficiary brings a claim in arbitration, both parties will also enjoy equally limited protection under the ECHR. Similarly, although the beneficiary of a unilateral arbitration clause can preclude litigation initiated by the non-beneficiary, later both parties will be in the same arbitration proceedings which provide them with equal protection. However, such a proposition disregards the fact that Article 6 ECHR contains two requirements relating to the equality of the parties: (1) equality within a procedure in the form of the equality of arms and (2) equality before a procedure is initiated in the form of equal access to a court. Although unilateral option clauses do not have implications for the first safeguard, they affect the latter.

\section{Summary}

Unilateral arbitration and unilateral litigation clauses affect the guarantees of Article 6 ECHR differently. A unilateral litigation clause constitutes a waiver by the nonbeneficiary of both the right of access to a court and the right of equal access to a court. Once the non-beneficiary signs a unilateral litigation clause, it is completely precluded from initiating litigation, whereas the beneficiary reserves this ability. In contrast, a unilateral arbitration clause allows the non-beneficiary to institute litigation, but the beneficiary retains the right to ask a court to refer the parties to arbitration. Hence, a unilateral arbitration clause constitutes a waiver by the non-beneficiary of only the right of equal access to a court. The last step to determine compatibility or otherwise of unilateral option clauses with the ECHR is to establish whether Article 6 ECHR allows the waiver of the right of equal access to a court by means of unilateral option clauses.

\section{F. LEGALITY OF THE WAIVER OF THE RIGHT OF EQUAL ACCESS TO A COURT}

The ECtHR's jurisprudence has developed several requirements which must be satisfied for an advance waiver of a right guaranteed by Article 6 ECHR to be valid. In particular, the waiver must be a permissible waiver, agreed by a party of its own free will, expressed in an unequivocal manner, and accompanied by 'minimum guarantees' commensurate with the importance of the right waived. This section analyses whether the waiver of the right of equal access to a court by means of unilateral option clauses satisfies these conditions. 


\section{Permissibility of the Waiver}

As a preliminary matter, it must be established that the ECHR permits a waiver of a particular right. In Albert and Le Compte v Belgium the ECtHR stated that some of the rights guaranteed by the ECHR are so fundamental and important that no one can be deprived of their benefit, even if a person acts entirely voluntarily and absent coercion. ${ }^{97}$ The ECtHR has not yet clearly distinguished waivable and non-waivable rights. ${ }^{98}$ Moreover, the jurisprudence of the ECtHR has not developed a test to differentiate between the two. The only guidance is that a waiver of a right is not permissible if the letter or the spirit of the ECHR prohibits a waiver. ${ }^{99}$

In light of the lack of detailed criteria, the permissibility of the waiver of the right of equal access to a court can be assessed through comparison with other guarantees of Article 6 ECHR, namely, rights whose waivability were examined by either the ECtHR or commentators.

One the one hand, the right of equal access to a court is closely linked to the right of equal treatment. Both are the manifestations of the principle of equality; the first safeguards equality between the parties before the initiation of proceedings, whereas the second one guarantees equality after an action is brought. Although the ECtHR has not yet addressed the question of whether the right of equal treatment can be waived, authors generally agree that it is a non-waivable guarantee. ${ }^{100}$ It can therefore be argued that since equality within a procedure cannot be waived, the same should be true for equality before an action is instituted. Such reasoning warrants the conclusion that the ECHR does not permit the waiver of the right of equal access to a court.

On the other hand, the right of equal access to a court constitutes a guarantee that is derivative from the right of access to a court. As demonstrated in section $C(3)$, the right of access to a court can be validly waived by an arbitration agreement. A unilateral option clause is a special type of arbitration agreement. Its legal consequences are not identical but are quite similar to a traditional arbitration agreement. On this basis, an argument can be advanced that the waiver of the right of equal access to a

\footnotetext{
${ }^{97}$ Albert and Le Compte v Belgium App no 7299/75 and 7496/76 (ECtHR, 10 February 1983) [35].

${ }^{98}$ Lorna McGregor, 'Alternative Dispute Resolution and Human Rights: Developing a Rights-Based Approach through the ECHR' (2015) 26 EJIL 607, 618.

${ }^{99}$ H v Belgium App no 8950/80 (ECtHR, 30 November 1987) [54]; Hermi v Italy App no 18114/02 (ECtHR, 18 October 2006) [73]; Mulosmani v Albania App no 29864/03 (ECtHR, 8 October 2013) [126]. 100 See an overview of the literature in Kruminš (n 66) 314; Landrove (n 65) 86.
} 
court is also permissible. Moreover, the waiver of the right of equal access to a court might be regarded as less onerous for a party compared to the waiver of the right to a court. In the latter situation, a party is completely precluded from access to a court. In contrast, by waiving the right of equal access to a court, a party merely makes its access to a court more difficult. In particular, upon entering into a unilateral arbitration clause, a party consents to an arrangement where its access to a court will be conditional on the will of the other party. Hence, it would be inconsistent to allow a waiver which has more significant implications for an individual, while prohibiting a less onerous one.

The second line of reasoning seems more convincing. As a response to the argument comparing the equality of arms and the right of equal access to a court, it should be noted that these guarantees are not of the same importance. The ECtHR's reasoning in Golder $v$ the United Kingdom implies that the right of access to a court is not a value in itself, but rather is a safeguard which makes it possible to benefit from the procedural guarantees of Article 6 ECHR. ${ }^{101}$ Unlike the principle of equality of arms, which protects the ability of a party to present its arguments and therefore directly affects the outcome of a case, the right of equal access to a court has much less influence on a final determination of the parties' rights and obligations. It would follow that equality before the initiation of proceedings cannot be placed on the same level with equality within a procedure. Hence, the fact that the right of equal treatment cannot be waived does not necessarily entail that the same applies to the right of equal access to a court.

To sum up, the ECtHR's case law neither definitely answers the question whether the right of equal access to a court is permissible, nor does it provide adequate guidance on the issue. Nevertheless, there are several points suggesting that this question should be answered in the affirmative. First, the right of equal access to a court constitutes an element of the right of access to a court, which may be waived by the parties as the ECtHR has clearly established. Second, the waiver of the right of equal access to a court is less onerous for an individual than the waiver of the right to a court. Hence, it would be more consistent to view the right of equal access to a court as a waivable guarantee of Article 6 ECHR, rather than a non-waivable one.

\section{Absence of Constraint}

${ }^{101}$ Golder (n 42) [35]. 
The ECtHR's jurisprudence has clearly established that a valid waiver of a right shall be agreed by a party 'of his own free will'. ${ }^{102}$ In Deweer v Belgium, the ECtHR stipulated that for a valid waiver of the right of access to a court 'absence of constraint is at all events one of the conditions to be satisfied'. ${ }^{103}$ Although the case law indicates that 'any form of constraint must be absent', ${ }^{104}$ economic duress does not necessarily entail that a waiver is involuntary. ${ }^{105}$ At the same time, together with voluntariness, the ECtHR requires that a waiver of a right is knowing and intelligent. ${ }^{106}$

Smit argues that the only situation where a party would agree to a unilateral option clause is where it is acting under economic compulsion or does not fully comprehend the disadvantageous position it is entering into. ${ }^{107}$ Although these considerations might be relevant in cases involving consumers, it would be difficult to defend this position where a unilateral option clause is concluded between commercial parties.

First, it appears from the ECtHR's jurisprudence that a situation where one party to a contract makes its conclusion conditional upon the inclusion of a unilateral option clause cannot be considered economic duress capable of invalidating the agreement. In Axelsson $v$ Sweden, the owners of the taxi company argued that an arbitration clause contained in the membership agreement with a taxi association violated their right of access to a court. ${ }^{108}$ The ECtHR did not find a violation, although the applicants claimed it was 'economically essential to join' the association. ${ }^{109}$ Second, it would be unreasonable to assume that a commercial party, as opposed to a consumer, is not aware of the consequences a unilateral option clause entails since a contract between businesses is usually a product of lengthy negotiations involving lawyers. The more realistic approach is that the agreement is a result of bargaining and the non-beneficiary

\footnotetext{
102 Petrina v Croatia App no 31379/10 (ECtHR, 13 February 2014) [45]; Dvorski v Croatia App no 25703/11 (ECtHR, 20 October 2015) [100]; Simeonovi v Bulgaria App no 21980/04 (ECtHR, 12 May 2017) [115].

${ }^{103}$ Deweer (n 54) [49].

${ }^{104}$ Marte Knigge and Pauline Ribbers, 'Waiver of the Right to Set-Aside Proceedings in Light of Article 6 ECHR: Party-Autonomy on Top?’ (2017) 34 JIA 775, 782.

105 ibid.

106 Pishchalnikov v Russia App no 7025/04 (ECtHR, 24 September 2009) [77]; Sakhnovskiy v Russia App no 21272/03 (ECtHR, 12 November 2010) [91]; Truten v Ukraine App no 18041/08 (ECtHR, 23 June 2016) [58].

107 Smit (n 94) 404.

${ }^{108}$ Axelsson and others $v$ Sweden, App no 11960/86 (ECtHR, 13 July 1990).

109 ibid.
} 
of a unilateral option clause accepts its disadvantage in exchange for some benefit under the contract.

Therefore, unless the conclusion of a unilateral option clause involved extraordinary circumstances such as duress, the waiver of the right of equal access to a court by a unilateral option clause satisfies the absence of constraint requirement.

\section{Unequivocal Manner}

Another criterion of a valid waiver of a right is that it 'must be established in an unequivocal manner'. ${ }^{110}$ The ECtHR's jurisprudence does not contain a clear definition of what constitutes 'unequivocal manner'. The ordinary meaning of 'unequivocal' is 'expressed in a clear and certain way'. ${ }^{111}$

Generally, this requirement does not mean that a waiver of a right shall be manifested in a written form. It can be demonstrated 'either expressly or tacitly'. ${ }^{112}$ However, the circumstances in which the ECtHR permits a tacit waiver concern cases where the question was whether the conduct of an individual within a procedure indicated a waiver of a right. ${ }^{113}$ Moreover, these cases dealt exclusively with a right to a public hearing. ${ }^{114}$ With respect to other rights guaranteed by the ECHR, the ECtHR has observed that 'the waiver of a right, even the mere right to a sum of money, must result from unequivocal statements or documents'. ${ }^{115}$ Also, in connection with the right of access to a court, commentators argue that given its importance and the fact that the NYC requires an arbitration agreement to be in writing, it is logical to presume that the waiver of the right has to be made in writing. ${ }^{116}$ There are no reasons why this should be different for the right of equal access to a court.

Therefore, with respect to the renunciation of the right of equal access to a court in the form of unilateral option clauses, the requirement of a waiver being express in an

\footnotetext{
${ }^{110}$ Natsvlishvili and Togonidze v Georgia App no 9043/05 (ECtHR, 29 April 2014) [91]; Correia de Matos v Portugal App no 56402/12 (ECtHR, 4 April 2018) [128].

$111 \quad$ Cambridge Dictionary, 'Unequivocal'

<https://dictionary.cambridge.org/dictionary/english/unequivocal> accessed 03 June 2018.

112 Schuler-Zgraggen v Switzerland App no 14518/89 (ECtHR, 24 June 1993) [58]; Şaman v Turkey App no 35292/05 (ECtHR, 5 April 2011) [32].

${ }_{113}$ An example is the failure to request a public hearing in Zagorodnikov v Russia App no 66941/04 (ECtHR, 7 June 2007) [25].

${ }^{114}$ Zelst (n 24) 85.

115 Neumeister v Austria App no 1936/63 (ECtHR, 7 May 1974) [36] cited in Lucius Caflish, 'Waivers in International and European Human Rights Law' in Mahnoush H Arsanjani and Jacob Cogan (eds) Looking to the Future: Essays on International Law in Honor of W Michael Reisman (Martinus Nijhoff Publishers 2010) 424.

116 Zelst (n 24) 85.
} 
unequivocal manner includes the need for writing. A unilateral option clause satisfies this requirement unless it is drafted in unclear language.

\section{Appropriate Safeguards to the Waiver}

The ECtHR also requires that a waiver of a right is accompanied by 'minimum guarantees commensurate with its importance'. ${ }^{117}$ In the context of arbitration, the ECtHR has specified this requirement in two cases. ${ }^{118}$ In Suovaniemi, when considering a waiver of the right to challenge an arbitrator for the lack of impartiality, the ECtHR indicated two circumstances to explain why the waiver was accompanied by 'minimum safeguards': (1) despite being aware of grounds for challenging the arbitrator, the applicant approved him; and (2) the applicant was represented by a lawyer during arbitral proceedings. ${ }^{119}$

When assessing the validity of the waiver of the right of equal access to a court, it should be reiterated that the ECtHR's reasoning in Golder demonstrates that the right of access to a court is not a value in itself, but rather a safeguard which makes it possible to benefit from the procedural guarantees of Article 6 ECHR. ${ }^{120}$ If applied to unilateral option clauses, this logic suggests that although the non-beneficiary does not have access to a court with full benefits of Article 6 ECHR, the crucial point is that the nonbeneficiary is still able to avail himself of the ECHR's protection within arbitral proceedings. As demonstrated in section $\mathrm{C}(3)$, an arbitration agreement does not automatically entail the renunciation of all guarantees contained in Article 6 ECHR. Moreover, arbitration constitutes one of the means under Article 13 ECHR for an individual to obtain a remedy for the violation of his rights. ${ }^{121}$ Some authorities interpret the ECtHR's decisions as indirectly confirming that arbitrators are under an obligation to observe Article 6 ECHR. ${ }^{122}$ Similarly, national courts in ECHR Contracting States

\footnotetext{
117 Thompson $v$ the United Kingdom App no 36256/97 (ECtHR, 15 June 2004) [43]; Litwin v Germany App no 29090/06 (ECtHR, 3 November 2011) [37].

118 Eiffage $v$ Switzerland App no 1742/05 (ECtHR, 15 September 2009); Suovaniemi (n 59) cited in Knigge and Ribbers (n 104) 786.

${ }^{119}$ Suovaniemi (n 59).

${ }^{120}$ Golder (n 42) [35].

${ }^{121}$ See section $\mathrm{C}(2)$ above.

122 Jaksic (n 29) 164.
} 
have ruled that arbitral proceedings must comply with either Article 6 ECHR as such, ${ }^{123}$ or its underlying principles. ${ }^{124}$

It seems that by waiving the right of equal access to a court as compared to its contractual partner, the non-beneficiary of a unilateral option clause does not put itself in a position which can be described as lacking appropriate safeguards for the protection of its interests. The non-beneficiary is still able to have its claims decided in accordance with the fundamental principles of due process guaranteed by Article 6 ECHR, namely the right of equal treatment and the right to be heard. It is true, however, that the beneficiary of a unilateral option clause has the advantage of, for example, choosing to initiate arbitration if it deems confidential proceedings to be in its interests, while the non-beneficiary could have benefited more from public hearing in a court. Also, the beneficiary has the opportunity to make use of a home court advantage by initiating litigation in a jurisdiction completely unfamiliar to the non-beneficiary. Nevertheless, it appears that the availability of arbitration to the non-beneficiary is in itself a 'minimum safeguard' as required by the ECtHR that is sufficient to justify the renunciation of the right of equal access to a court.

\section{Summary}

The waiver of the right of equal access to a court by means of unilateral option clauses satisfies the requirements for a valid waiver of a right under Article 6 ECHR. In particular, the ECHR permits the waiver of the right of equal access to a court. A unilateral option clause is normally agreed by a party 'of his own free will' and is expressed in unequivocal language. The waiver of the right of equal access to a court is accompanied by 'minimum guarantees commensurate with its importance' since the non-beneficiary is still able to have its claim considered in arbitral proceedings where guarantees of Article 6 ECHR are partially applicable.

\section{G. CONCLUSION}

This article assessed unilateral option clauses from the perspective of the ECHR. The analysis of decisions rendered by English and Russian courts revealed that these

\footnotetext{
${ }^{123}$ P.S. v. Société de droit du Delaware (...) 'C.C.S' (30 March 2011, Court of First Instance of Brussels) noted in Bernard Hanotiau, 'P.S. v. Société de droit du Delaware (...) 'C.C.S.', Court of First Instance of Brussels, 30 March 2011' (A contribution by the ITA Board of Reporters, Kluwer Law International). 124 4A_370/2007 (Judgment of 21 February 2008, First Civil Law Court of Switzerland) [4.3.2] cited in Daniel Girsberger and Nathalie Voser, International Arbitration: Comparative and Swiss Perspectives (Third Edition) (Schulthess Juristische Medien AG 2016) 406.
} 
agreements might be challenged on the basis of Article 6 ECHR. In particular, the cases showed that unilateral option clauses trigger not only the right of access to a court, but also the right of equal access to a court. It was then established that unilateral arbitration and unilateral litigation clauses affect Article 6 ECHR guarantees differently. A unilateral litigation clause constitutes a waiver by the non-beneficiary of both the right of access to a court and the right of equal access to a court. The right of access to a court is waived because once the non-beneficiary signs a unilateral litigation clause, it can no longer go to a court. The right of equal access to a court is waived since the beneficiary, unlike the non-beneficiary, reserves an ability to initiate litigation. A unilateral arbitration clause constitutes a waiver by the non-beneficiary of only the right of equal access to a court. The right of access to a court is not waived because the nonbeneficiary retains an ability to bring its claim before a court. The right of equal access is waived since the beneficiary can rely on its arbitration option and preclude a court action instituted by the non-beneficiary. Having scrutinised the waiver of the right of equal access to a court by means of unilateral option agreements against requirements developed in the ECtHR's jurisprudence, it is concluded that these clauses are compatible with the ECHR. 
